\title{
TREATMENT OF DISTILLERY SPENT WASH FOR IRRIGATION PURPOSE BY USING SAND AS ADSORBENT
}

\author{
Bharat Kumar $^{1 *}$, Akash Negi ${ }^{2}$, Hashanpreet Dhaliwal ${ }^{3}$, Sparsh Munakhia $^{4}$ \\ *1 Department of Chemistry Doon International School, Dehradun, 248001, U.K., India \\ 2, 3, 4 Student Class XI 2016-2017, Doon International School, Dehradun, 248001, U.K., India \\ *1singhal.bharat@rediffmail.com, ${ }^{2}$ akashnegi1736@gmail.com, \\ 3hashanpreetdhaliwal@gmail.com, ${ }^{4}$ sparsh.munakhia@yahoo.com
}

Corresponding Author: -

Email: singhal.bharat@ rediffmail.com

\begin{abstract}
: -
Sand treatment of distillery effluent has great potential as a sustainable method as it is a low cost method. The aim of this investigation is to study the sand treatment method for purification of distillery spent wash. For this, the study encompassing evaluation of reduction of various physical chemical parameters ( $\mathrm{pH}, \mathrm{COD}, \mathrm{TS}, \mathrm{TDS}, \mathrm{Ca}, \mathrm{Mg}, \mathrm{Na}$ and $\mathrm{K}$ ) of distillery spent wash was checked by passing through the sand column. The distillery effluent was acidic (pH 4.7) and dark brown in color which often cause psychological fear in farmers for utilization. Sand treatment of spent wash exhibited good reduction in COD, TS, TDS, Mg, Na, Ca, after 72-hour treatment and increase in pH toward pH 7. Treated spent wash showed a good growth of wheat seeds.
\end{abstract}

Keywords: "Spent wash”, "Absorbent”, "Sand", "Chemical parameter", "Irrigation”. 


\section{INTRODUCTION}

Increasing industrialization for sustaining economic growth and ever-increasing population is leading to the pollution of the environment due to the disposal of untreated effluents. Various pollutants produced in industries directly or indirectly and result in cumulative pollution of our environment. These pollutants cause severe degradation in pedosphere, hydrosphere, atmosphere and thus causing a potential menace to the health and welfare of mankind.

Wastes generated from various industries include the effluents from textile, chemical fertilizers, pulp and paper, petro chemical and breweries, metal processing, automobile manufacturing, power=plant including leather and tannery industries and thermal and nuclear power plant etc.

Improper disposal methods and inadequate treatment of toxic constituents from different industries have led to the widespread contamination of surface and ground waters and have made the water resources unfit for usage. Hence there is an urgent need for waste water treatment.

Environmental pollution by distillery industry has recently been the subject of much research. Distillery waste is one of the major wastes of ecological concern. It is a complex, caramelized and recalcitrant waste containing high percentage of organic matter and heavy metal ions (Nemade and Shri vastava, 2000). This causes pollution in receiving waters as well as in land.

To safeguard humanity, we require conductive and congenial environment for which the industrial pollution need to be minimized substantially. To achieve this, several physical, chemical and biological methods/techniques have been developed and being practiced in very few industries along with distilleries (Lin et al 2003). The reason of limited scope of these techniques lies with their adhered economical solution of the pollution abatement problems, adsorption treatment has been one of the cost-effective method and being practical unintentionally during crop irrigation. Once the industrial effluent is suitably treated, it could be applicable for crop irrigation. The application of effluent to short rotation fores try crop is a treatment system which if properly designed and maintained could both increase the productivity of the crops and reduce the waste disposal problem (Sims and Riddell 2001). Keeping this in view, the present study therefore is planned to investigate the land treatment of distillery effluent with following objectives

1. To characterize physico-chemical characteristics ( $\mathrm{pH}$, color, COD, TS, TDS, $\mathrm{Na}, \mathrm{K}, \mathrm{Mg}$, and Ca) of distillery effluent (spent wash).

2. To study the impact of Sand as adsorbent on spent wash quality.

\section{SAND'S PHYSICAL PROPERTIES AND PROCESSES}

The physical aspects of waste treatment through sand systems involve the processes of filtration and dilution. As water moves through sand, suspended particles are removed by filtration and filtrate may be diluted with water. The rate of these processes is affected by sand's physical properties i.e. the relative proportion of mineral particles of different sizes present in the sand. Soily sand is less porous, have low filtration rates and retain more water. In contrast, soily sand has low infiltration rates, retains much water and may be poorly drained.

\section{MATERIAL AND METHODS}

3.1 Sample collection

Effluents waste water (spent wash) was taken from a distillery, located in Dehradun. The factory uses molasses as the raw material. The effluent flows out into "River Song" that passes through nearby villages. Samples were collected at main outlet of distillery on date 02.11.2016. Samples were collected five times at weekly from November to December 2016 in clean sterile plastic container and stored at $4^{\circ} \mathrm{C}$ in a refrigerator.

3.2 Effect of sand as adsorbent on various physiochemical Characteristics of distillery effluent Five plastic pots were filled with $2 \mathrm{~kg}$ sand each and wheat was grown (Triticum aestivum) Variety UP2329, after 20days of growth, pots were irrigated with spent wash and the $5^{\text {th }}$ pot was used as control. On each irrigation date one liter of treated effluent was poured in each pot. 24 hour treated, 48 hour treated and 72 hour treated spent wash was used in pot 1, pot 2, pot 3 and pot 4 for irrigation. Same time treated samples were collected in sterile reagent bottles for physical and chemical tests.

\subsection{Physico Chemical Parameters Selected for analysis}

3.3.1 Physical Parameters $\mathrm{pH}$, TS, TDS.

3.3.2 Chemical parameters $\mathrm{COD}, \mathrm{Ca}, \mathrm{Mg}, \mathrm{Na} \& \mathrm{~K}$.

3.4 Measurement of Total Solids (TS)

Total solids were determined by measuring the residue left after evaporation of unfiltered samples (APHA 1995).

3.4.1 Calculations Total Solids $(\mathrm{mg} / \mathrm{l})=(\mathrm{A}-\mathrm{B}) \mathrm{X} 1000 /$ Vol. of sample $(\mathrm{ml})$.

Where $\quad A=$ Dry weight of residue + dish $(\mathrm{mg})$

$\mathrm{B}=$ Weight of dish (mg).

\subsection{Total Dissolved Solids (TDS)}

Total dissolved solids are determined by measuring the residue left after evaporation of filtered sample (ALPHA 1995).

\subsection{Measurement of $\mathbf{p H}$}

The $\mathrm{pH}$ of effluent was measured by $\mathrm{pH}$ meter using a glass electrode and universal $\mathrm{pH}$ indicator solution. 


\subsection{Measurement of COD}

It is the maximum amount of oxygen that can be consumed by the organic matter in the sample for complete oxidation. It is measured by method described in APHA (1995).

In this ferrous ammonium sulphate $(0.25 \mathrm{M})$ and potassium dichromate $\left(\mathrm{K}_{2} \mathrm{Cr}_{2} \mathrm{O}_{7}\right)$ of $0.04167 \mathrm{M}$ are used for titration.

\subsubsection{Calculations}

COD $(\mathrm{mg} / \mathrm{l})=(\mathrm{A}-\mathrm{B}) \mathrm{X} \mathrm{M} \times 1000 /$ volume of Sample in $\mathrm{ml}$.

Where $\quad \mathrm{A}=$ Volume of FAS used for blank in $\mathrm{ml}$.

$\mathrm{B}=$ Volume of FAS used for sample in $\mathrm{ml}$.

$\mathrm{M}=$ Molarity of FAS.

FAS $=$ Ferrous ammonium sulphate.

\subsection{Determination of $\mathrm{Ca}$ and $\mathrm{Mg}$}

It was measured by complexo metric titration using ethylene di amine tetra acetic acid (EDTA).

(Schwazenbach).

\subsection{Determination of $\mathrm{Na}$ and $\mathrm{K}$}

A characteristic light is produced due to excitation of electrons when the samples with $\mathrm{Na} / \mathrm{K}$ sprayed into a flame. The intensity of this characteristic's radiation is proportional to the concentration of $\mathrm{Na} / \mathrm{K}$ and can be read at $529 / 768 \mathrm{~mm}$ by using suitable optical filter device (Tondon 1998)

\section{RESULT}

Table 1.1 shows that visible color of distillery effluent was dark brown having foul smell, with acidic nature ( $\mathrm{pH} 4.7)$ and contain TS-10000mg/l, TDS-7600mg/l, pH-4.7, COD-8200mg/l, Ca-2200mg/l, Mg1730mg/l, Na-800mg/l, and K$1700 \mathrm{mg} / \mathrm{l}$. Table 1.2 and 1.3 reveals the removal of pollutants from distillery spent wash, which is seen maximum after 72 hour treatment with sand followed by 48 hour and minimum in 24 hour treatment. After treatment with sand at various time intervals, $\mathrm{pH}$ of spent was increased significantly from 4.7 to 5.4 after 72 -hour treatment (Table 1.2). COD, TS, TDS were found minimum after 72-hour treatment with sand (Table 1.2), maximum reduction in $\mathrm{Ca}, \mathrm{Mg}, \mathrm{Na}$, and $\mathrm{K}$ is seen at after 72-hour treatment with sand (Table 1.2 and 1.3). Maximum reduction in TS, TDS, COD, pH and metallic ions is observed after 72-hour treatment following by 48-hour treatment and minimum change after 24-hour treatment.

\section{DISCUSSION}

Sand is a good adsorbent for color removal from spent wash and referred discoloration up to $90 \%$ while discoloration decreased with increasing concentration, reduction in COD from distillery effluent was found maximum $36.36 \%$ by using sand. Changed soil characteristic result in an altered growth of wheat plant and growth of wheat was increased by irrigation with treated for 72 hour. Effluent was purified at a good level by sand.

\section{CONCLUSION}

On the basis of experimental result it could be conclude that sand treatment by using sand is one of the best methods for removal of pollutants from distillery spent wash and we can reshape the effluent characteristics so it could be used as irrigation water to reduce the pressure of application of fertilizers and normal water irrigation. The study also revealed that the diluted effluent could be beneficial for better growth of wheat plant which also enhances wheat seed germination. The adsorbent by using sand treatment method of effluent could be profitably practiced for removing the pollutants and thus avoiding the ground water contamination and its environmental impacts and sand can be used for this purpose successfully.

\section{REFERENCES}

[1].Abumaizar,R. and Khan, L.I 1996, "Laboratory investigation heavy metal removal by soil washing" in Journal of the Air and Waste Management Association. 46:765-768.

[2].APHA, AWWA, WPCA 1995, Starndard Methods for the examination of water and waste water, A.M. Publ. Health Assoc, New York, $19^{\text {th }}$ (ed.).

[3].Baruah, A.K.: Sharma,R.N Borah ,G.C., 1998, "Impact of sugar mill and distillery effluents on water quality of river Crelabil Assam" in Indian J.of Environ.Health, 3 (94):288-293.

[4].Binklay,W.A and Wolform M.L. 1997 , "Composition of Cane juice and Cane final molasses" in Advances in carbohydrate chemistry.Ed C.S.Hundsor and M.L. Wolform Academic Press.Inc. Pub, New York, U.S.A. 8-29.

[5].Bharat kumar 2015, "Treatment of Distillery Effluent Using Activated Charcoal, Fly Ash, Wood Ash for Irrigation Purpose", in International Journal of Novel Research in Life Sciences Vol. 2, Issue 2, pp: (27-30).

[6].Chandra, R. 1996, "Biodegradation of distillery effluent isolation and characterization of microbial consortium", in Indian J. Env. Prom., 16(5):352-355.

[7].Chandra,R. and Panday, P.K.2000, “ Decolourisation of anaerobically treated distillery effluent by activated charcoal adsorption method", in Indian J. Env. Prot, 21(2):134-137. 
[8].Cheriminisinoff, P.N. 1995, Hand book of water and waste water treatment technology, Marcel Dekker Inc. New York.

[9].Chhonkar, P.K.Datta, S.P.Joshi, H.C. and Pathak H., 2000, "Impact of industrial effluents on soil health and agriculture. Indian experience: Part I- distillery and paper mill effluent", Journal and Scientific and Industrial Research 59(5):350-361.

[10]. Jain,S. and Singh, M.K. 1998 water pollution control equipments and instruments. In Industrial safety and pollution control hand book. Ed. J.Nagarey, A joint publication of National Safety Council Associates (Data) Publishers Pvt.Ltd. Secundarabad, India, 291-306.

[11]. Kadirvelu, K.:Palanivel, M.Kaltana,R. and Rajes wari, S.2000 b. "Activated carbon prepared from agricultural bi product for the treatment of dyeing waste water", Bioresource Technol.75:25-27.

[12]. Khoshoo, T.N.1999, Environmental priorities in India and sustainable development, Presidential address, 73rd session. Indian Science Congress Association, New Delhi. 224.

[13]. Lee, C.K,Low.K.S. And Gan, P.y. 1999, "Removal of some organic dyes by acid spent beleaching earth", Environ.Technol, 20:99-104.

[14]. Lin, S.H. and Kiang, C.D.2003, "Combined physical chemical biological treatment of waste water containing organics from a semiconductor plant", Journal of Hazardous material,97(1-3): 159-171.

[15]. Menambal, T.1999, "Experimental coagulants responses in dicolourization of treated distillury effluent", in Advances in waste water treatment ed. T.K. Goel, Techno science Publication Jaipur, India, 240-249.

[16]. Nemade, P. N and Shrivastava, V.S. 1997, "Metals in different effluents and their impacts on ground water and plant tissues", Indian J.Env.Prot, 17(2):133-136.

[17]. Nriagu, J.O.and Pacyna. J.M.1998, "Quantitative assessment of worldwide contamination of air water and soil by trace metals", Nature, 333:134-139.

[18]. Pathade, G.R., 2001 "A review of current technologies distillery waste water treatment", in Advances in industrial waste water treatment ed.P.K. Goel, Techno science Publication.

[19]. Royguard, J.K.F. Green, S.R.Clophier,V.E.:Sims, R.E.H. and Bolan,N.S.1999, “ Short rotation and forestry for land treatment", in Australian Journal of soil Research 37(5):983-991.

[20]. Sahu, A.K. and Patel, M.1997, "Effluent treatment technologies based on adsorption and coagulation for environment in pulp and paper industry", IPPTA,7(1):18-28

[21]. Sharma O.P., Bangar K.S., Jain R. and Sharma P.K 2004, "Heavy metal accumulation in soil irrigated by municipal and industrial effluent", J.Environ.Science and Engg. 46(1):65-73.

[22]. Srivastava A. and Pathak A.N, 1998, "Modern technologies for distillery effluent treatment", J. of Scientific and Industrial Research, 57:388-392.

Table: 1.1

Effect of Sand on Color and Odor of Spent Wash

\begin{tabular}{|l|l|lll|}
\hline Parameters & Original Sample & \multicolumn{3}{|l|}{ Sand } \\
\hline \multicolumn{2}{|l|}{} & $24 \mathrm{hr}$ & $48 \mathrm{hr}$ & $72 \mathrm{hr}$ \\
\hline Color & Dark brown & Dark brown & Brown & Brown \\
\hline Odor & Foul Smell & Molasses odor & $\begin{array}{l}\text { Molasses } \\
\text { odor }\end{array}$ & $\begin{array}{l}\text { Molasses } \\
\text { odors }\end{array}$ \\
\hline
\end{tabular}

Table: 1.2

Physico Chemical Characteristics of Distillery Spent Wash treated with Sand at Various Irrigation Periods

\begin{tabular}{|l|l|l|l|l|}
\hline \multirow{2}{*}{ Para-meters } & \multirow{2}{*}{$\begin{array}{l}\text { Original } \\
\text { sample }\end{array}$} & \multicolumn{3}{|l|}{ Normal sand } \\
\cline { 3 - 5 } & & $24 \mathrm{hr}$ & $48 \mathrm{rh}$ & $72 \mathrm{hr}$ \\
\hline $\mathrm{TS}$ & 10000 & 6400 & 6200 & 5800 \\
\hline $\mathrm{TDS}$ & 7600 & 5400 & 5200 & 5000 \\
\hline $\mathrm{pH}$ & 4.7 & 5.1 & 5.3 & 5.4 \\
\hline $\mathrm{COD}$ & 8200 & 5816 & 5464 & 5218 \\
\hline $\mathrm{Ca}$ & 2200 & 760 & 720 & 680 \\
\hline $\mathrm{Mg}$ & 1730 & 800 & 600 & 580 \\
\hline $\mathrm{Na}$ & 800 & 620 & 540 & 500 \\
\hline $\mathrm{K}$ & 1700 & 1060 & 1020 & 880 \\
\hline
\end{tabular}

NOTE: All values in $\mathrm{mg} / \mathrm{lit}$ except $\mathrm{pH}$ 


\section{TABLE 1.3:}

Percent Change in Physic Chemical Characteristics of Distillery Spent Wash Treated with Sand at Various Irrigation Periods

(+Increase,-Decrease)

\begin{tabular}{|l|l|l|l|l|}
\hline Para-meters & $\begin{array}{l}\text { Original } \\
\text { sample }\end{array}$ & \multicolumn{4}{l|}{ Normal sand } \\
\cline { 3 - 5 } & & $24 \mathrm{hr}$ & $48 \mathrm{rh}$ & $72 \mathrm{hr}$ \\
\hline $\mathrm{TS}$ & 10000 & -36 & -38 & -42 \\
\hline $\mathrm{TDS}$ & 7600 & -28.95 & -31.58 & -34.12 \\
\hline $\mathrm{pH}$ & 4.7 & +5.51 & +12.77 & +14.89 \\
\hline $\mathrm{COD}$ & 8200 & -29.07 & -33.36 & -36.36 \\
\hline $\mathrm{Ca}$ & 2200 & -65.45 & -67.27 & -69.09 \\
\hline $\mathrm{Mg}$ & 1730 & -53.76 & -65.31 & -66.47 \\
\hline $\mathrm{Na}$ & 800 & -22.5 & -32.5 & -37.5 \\
\hline $\mathrm{K}$ & 1700 & -37.65 & -40 & -48.24 \\
\hline
\end{tabular}

